\title{
Factors Affecting Medical Nutritional Therapy Among Type 2 Diabetes Patients Attending Clinic at Kenyatta National Hospital
}

\author{
J.S. Asati ${ }^{1}$, Dr. P. Wanzala ${ }^{2}$, Prof A. Makokha ${ }^{3}$ \\ ${ }^{1}$ Jomo Kenyatta University of Agricultue and Technology-Juja, Kenya \\ ${ }^{2} \mathrm{PhD}, \mathrm{MPH}, \mathrm{MD}($ Kenya Medical Research Institute-Nairobi Kenya)
}

${ }^{3}$ Professor, PhD, MPhil, BSc (Jomo Kenyatta University of Agriculture and Technology-Department of Nutrition and Diatetic,Nutritional Biochemistry and Public Health-Juja, Kenya

\begin{abstract}
Objective: }}$ To determine patient related factors affecting Medical Nutrition Therapy among type 2 diabetes patients. Design: A descriptive cross sectional study. Setting: Kenyatta National Hospital, Nairobi County, Kenya. Subjects: 422 two type 2 diabetes patients. Results: $236(55.9 \%)$ Females and 186(44.1\%) male as well has 7 professional healthcare providers were interviewed. $47.9 \%$ of the respondents were aged between 40 - 59 years, with the lowest proportion aged less than 30 years (4.5\%). Not following recommended Medical Nutritional Therapy (MNT) was significantly associated withTertiary level of education (AOR=6.97; 95\% CI: 2.69 - 18.05; p<0.001). As well not following recommended Medical Nutritional Therapy (MNT) was significantly associated with getting to the diabetes. clinic by other means other than walking (AOR=3.49; 95\% CI: $1.56-7.80 ; p=0.002)$, irregular visits based on doctor's appointment or when sick $(A O R=3.65 ; 95 \%$ CI: 1.73 - 7.71; $p=0.001)$, duration of time taken during treatment determining how serious the client takes the treatment $(A O R=1.75 ; 95 \%$ CI: $1.09-2.82 ; p=0.020)$, regular eating of food that is not prepared according to recommended diet $(O R=3.78 ; 95 \%$ CI: $1.29-11.08 ; p=0.016)$. Conclusion: Not following recommended Medical Nutrition Therapy was as a result of irregular visits to the diabetes clinic, eating away from home, travelling to clinic by other means other than walking, waiting for more than two hour before receiving treatment at the diabetes clinic and not having enough healthcare providers. For a better following of recommended Medical Nutrition Therapy, these factors need to be addressed.
\end{abstract}

Keywords: Diabetes, medical, nutrition, therapy

\section{Introduction}

Diabetes Mellitus, commonly referred to as diabetes is a group of metabolic disorders characterized by high blood sugar, either because the body is not able to produce enough insulin or because the body cells are not able to respond to insulin or both. The disease is considered as the most psychologically and behaviorally demanding of the chronic diseases [1]. In 2003, 194 million people aged between 20 and 79 had diabetes [2] and according to IDF, 422 million people had diabetes in 2016 and this will have risen to 592 million by 2035 [3]. $80 \%$ of people with diabetes live in lowand middle-income countries. The largestnumber of people with diabetes areaged between 40 to 59 years [4]-[6].175 million people with diabetes are undiagnosed [3]. Diabetes caused 4.6 million deaths in 2011[7].14.7 million Adults in the Africa Region are estimated to have diabetes, with a regional prevalence of $3.8 \%$. Diabetes not only reduces quality of life and life expectancy but also puts economic burden individuals as well as the government [2]. Thus, strategies to mitigate both the human and economic burden are urgently needed.One of the strategies is simple lifestyle interventions to further harness the effectiveness of the medical endeavors to eliminate Type 2 diabetes[8],[9]. Several factors account for this chronic disease epidemic, including behavioral elements (improper nutrition, for example, increased fat consumption; decreased physical activity; obesity); demographic changes (aging, increased growth of at-risk populations); improved ascertainment and surveillance systems that more completely capture the actual burden of diabetes; and the relative weakness of interventions to change individual, community, or organizational behaviors [10].

The American Dietetic Association, the professional organization of RDs, defines the nutrition counseling component of MNT as supportive processes to set priorities, establish goals, and create individualized action plans which acknowledge and foster responsibility for self-care. With the increase the number of diabetes cases especially in developing countries, and with its short and long term complications, there is urgent need for diabetic patients to adhere and maintain the American Diabetic Association's Clinical Practice recommendations of tight plasma glucose control of $80-120 \mathrm{mg} / \mathrm{dl}$ for fasting glucose measurement, eat as recommended, perform other self-care activities and go for checkup as necessary [11].

Evidence from randomized controlled trials, observational studies and meta-analyses has shown that nutrition intervention which is basically dietary modification, improves metabolic outcomes, such as blood glucose and $\mathrm{hbA}_{1 \mathrm{C}}$ [12]-[14]. Thus dietary management is considered key in diabetes management [15]. It is founded on healthy eating in the premise of social, cultural and psychological influences on food choices [16] 


\section{International Journal of Science and Research (IJSR)}

ISSN (Online): 2319-7064

Index Copernicus Value (2016): 79.57 | Impact Factor (2015): 6.391

\section{Materials and Methods}

\subsection{Study area}

The study was conducted at Kenyatta National Hospital located in Nairobi the capital city of Kenya, formerly under Nairobi Province (now known as Nairobi County). It is the largest public health facility in the country and is a referral hospital. The hospital is strategically located and is easily accessible. The hospital operates a mini diabetes clinic all days of the week and a major diabetes clinic once a week

\subsection{Study population}

Type 2 diabetes attending Kenyatta National Hospital diabetes clinic as well as health care professionals attending to the Type 2 diabetes patients at Kenyatta National Hospital. A total of 420 patients and 7 healthcare providers were interviewed.

\subsection{Inclusion criteria}

Type 2 diabetes patients who had been attending clinic for more than 3 months who consented to the interview. Healthcare providers attending to type 2 diabetes patients and who accepted to be interviewed.

\subsection{Exclusion Criteria}

Non type 2 diabetes patients, those type 2 diabetes patients who had not been attending clinic for more than 3 months, as well as those who had been attending but did not consent. Healthcare providers not attending to type 2 diabetes patients.

\subsection{Collection of data}

Data was collected using structured questionnaires by trained research assistants and key informant interview by the principle researcher. The Questionnaire administered to the patients covered demographic factors, history of diabetes and accessibility of the diabetes clinic, counselling services at the diabetes clinic and availability of recommended Medical Nutrition Therapy.

\subsection{Statistics}

Data collected was double entered into a computer using Microsoft access. It was cleaned using AP Info and analyzed using SPSS.The results obtained were expressed as percentages for the various segments of the questionnaire. Logistic regression was then used to determine the factors that were associated with not following recommended Medical Nutrition Therapy.

\section{Results}

A total of 422 patients and 7 healthcare providers were interviewed using structured questionnaire and key informant interviews respectively. Out of these, 236(55.9\%) were female and $186(44.1 \%)$ were male, 271(62.2\%) were following against 151(35.8\%) who were not following recommended Medical Nutrition Therapy (MNT).
Thirteen factors were associated with not following recommended Medical Nutritional Therapy (MNT)at $\mathrm{p}<0.05$ during bivariate analysis were considered together in a multivariate analysis. Upon fitting the factors using Binary logistic regression and specifying 'backward conditional' method with removal at $\mathrm{p}<0.05$, six factors (Reduced model) were retained in the final analysis as shown in Table 1. The full model of potential factors associated with not following recommended Medical Nutritional Therapy (MNT) is presented in Table 2 .

Adjusting for other factors, and relative to non-formal education, not following recommended Medical Nutritional Therapy (MNT) was significantly associated with Primary(AOR=3.44; 95\% CI: 1.35 - 8.82; $\mathrm{p}=0.010)$, Secondary (AOR=3.48; 95\% CI: $1.40-8.66$; $=0.007)$, and Tertiary $(\mathrm{AOR}=6.97 ; 95 \% \mathrm{CI}: 2.69-18.05$; $\mathrm{p}<0.001)$ levels of education.

Not following recommended Medical Nutritional Therapy (MNT) was significantly associated with getting to the diabetes clinic by other means other than walking $(\mathrm{AOR}=3.49 ; 95 \% \mathrm{CI}: 1.56-7.80 ; \mathrm{p}=0.002)$.

Irregular visits based on doctor's appointment or when sick was significantly associated with not following recommended Medical Nutritional Therapy (MNT) $(\mathrm{AOR}=3.65 ; 95 \% \mathrm{CI}: 1.73-7.71 ; \mathrm{p}=0.001)$.

Relative to spending less than 30 minutes since arrival at the clinic up to the time the client is through with the treatment, spending 121 - 180 minutes was significantly associated withnot following recommended Medical Nutritional Therapy $(\mathrm{MNT})(\mathrm{AOR}=3.21 ; 95 \% \mathrm{CI}: 1.53-6.72 ; \mathrm{p}=0.002)$. Similarly, spending more than 180 minutes was significantly associated withnot following recommended Medical Nutritional Therapy (MNT) (AOR=2.58; 95\% CI: 1.31 5.08; $\mathrm{p}=0.006$ ).

Not following recommended Medical Nutritional Therapy (MNT) was significantly associated with agreement to the fact that 'duration of time taken determines how serious the client take the treatment' $(\mathrm{AOR}=1.75 ; 95 \% \mathrm{CI}: 1.09-2.82$; $\mathrm{p}=0.020)$.

Regular eating of food that is not prepared according to recommended diet wassignificantly associated with not following recommended Medical Nutritional Therapy $(\mathrm{MNT})(\mathrm{AOR}=3.78 ; 95 \% \mathrm{CI}: 1.29-11.08 ; \mathrm{p}=0.016)$.

Table 1: Reduced model showing factors associated with not following recommended Medical Nutritional Therapy (MNT)

\begin{tabular}{|c|c|c|c|c|}
\hline \multirow[b]{2}{*}{ Variables } & \multirow[b]{2}{*}{ AOR } & \multicolumn{2}{|c|}{$95 \% \mathrm{CI}$} & \multirow{2}{*}{$\begin{array}{c}\mathbf{p} \\
\text { value }\end{array}$} \\
\hline & & Lower & Upper & \\
\hline \multicolumn{5}{|l|}{ Highest level of education } \\
\hline Non-formal & 1.00 & & & \\
\hline Primary & 3.44 & 1.35 & 8.82 & 0.010 \\
\hline Secondary & 3.48 & 1.40 & 8.66 & 0.007 \\
\hline Tertiary & 6.97 & 2.69 & 18.05 & $<0.001$ \\
\hline \multicolumn{5}{|l|}{ Walking to the diabetes clinic } \\
\hline Yes & 1.00 & & & \\
\hline No & 3.49 & 1.56 & 7.80 & \begin{tabular}{|l|l|}
0.002 \\
\end{tabular} \\
\hline Frequency of coming for review & & & & \\
\hline
\end{tabular}

\section{Volume 6 Issue 12, December 2017}




\section{International Journal of Science and Research (IJSR) ISSN (Online): 2319-7064}

Index Copernicus Value (2016): 79.57 | Impact Factor (2015): 6.391

\begin{tabular}{|c|c|c|c|c|}
\hline Very frequent & 1.60 & 0.75 & 3.42 & 0.226 \\
\hline Frequent & 0.82 & 0.47 & 1.42 & 0.481 \\
\hline Somewhat/ Less frequent & 1.00 & & & \\
\hline $\begin{array}{r}\text { Irregular (On doctor's } \\
\text { appointment/ When sick) }\end{array}$ & 3.65 & 1.73 & 7.71 & 0.001 \\
\hline \multicolumn{5}{|c|}{$\begin{array}{l}\text { Time taken since arrival at the clinic up to the time the client } \\
\text { is through with the treatment }\end{array}$} \\
\hline$<30$ Minutes & 1.00 & & & \\
\hline $30-60$ Minutes & 1.66 & 0.78 & 3.53 & 0.187 \\
\hline $61-120$ Minutes & 1.13 & 0.49 & 2.63 & 0.768 \\
\hline $121-180 \mathrm{Mi}$ & 3.21 & 1.53 & 6.72 & 0.002 \\
\hline$>180$ Minutes & 2.58 & 1.31 & 5.08 & 0.006 \\
\hline \multicolumn{5}{|c|}{$\begin{array}{c}\text { Duration of time taken determine how serious the client take } \\
\text { the treatment }\end{array}$} \\
\hline Yes & 1.75 & 1.09 & 2.82 & 0.020 \\
\hline No & 1.00 & & & \\
\hline \multicolumn{5}{|c|}{$\begin{array}{l}\text { Frequency of eating food that is not prepared according to } \\
\text { recommended diet }\end{array}$} \\
\hline Regularly & 3.78 & 1.29 & 11.08 & 0.016 \\
\hline Occasionally & 0.94 & 0.52 & 1.68 & 0.822 \\
\hline Not at all & 1.00 & & & \\
\hline
\end{tabular}

Table 2: Full model on potential factors associated with Non adherence to Medical Nutritional Therapy (MNT)

\begin{tabular}{|c|c|c|c|c|}
\hline \multirow[b]{2}{*}{ Variables } & \multirow[b]{2}{*}{ OR } & \multicolumn{2}{|c|}{$95 \% \mathrm{CI}$} & \multirow{2}{*}{$\begin{array}{c}\mathrm{p} \\
\text { value }\end{array}$} \\
\hline & & Lower & Upper & \\
\hline \multicolumn{5}{|l|}{ Age in years } \\
\hline$<30$ & 0.77 & 0.17 & 3.54 & 0.738 \\
\hline $30-39$ & 1.02 & 0.33 & 3.13 & 0.967 \\
\hline $40-49$ & 1.18 & 0.45 & 3.11 & 0.731 \\
\hline $50-59$ & 0.85 & 0.33 & 2.23 & 0.747 \\
\hline $60-69$ & 0.78 & 0.32 & 1.90 & 0.580 \\
\hline 70 or more & 1.00 & & & \\
\hline \multicolumn{5}{|l|}{ Marital status } \\
\hline Single & 1.55 & 0.54 & 4.51 & 0.418 \\
\hline Married & 1.75 & 0.82 & 3.76 & 0.149 \\
\hline $\begin{array}{l}\text { Separated/ divorced/ } \\
\text { widowed }\end{array}$ & 1.00 & & & \\
\hline \multicolumn{5}{|l|}{ Occupation } \\
\hline Student & 4.57 & 0.28 & 73.80 & 0.285 \\
\hline Businessman/woman & 1.25 & 0.52 & 3.00 & 0.615 \\
\hline Formal employment & 0.64 & 0.22 & 1.82 & 0.399 \\
\hline Farmer & 1.30 & 0.55 & 3.08 & 0.554 \\
\hline Casual labourer & 0.76 & 0.27 & 2.15 & 0.604 \\
\hline Housewife/Retired & 1.00 & & & \\
\hline \multicolumn{5}{|l|}{ Highest level of education } \\
\hline Non-formal & 1.00 & & & \\
\hline Primary & 3.67 & 1.35 & 9.98 & 0.011 \\
\hline Secondary & 3.31 & 1.20 & 9.10 & 0.020 \\
\hline Tertiary & 7.37 & 2.37 & 22.93 & 0.001 \\
\hline \multicolumn{5}{|l|}{$\begin{array}{l}\text { When started attending the } \\
\text { diabetic clinic }\end{array}$} \\
\hline$<2000$ & 1.00 & & & \\
\hline $2000-2004$ & 1.23 & 0.56 & 2.73 & 0.608 \\
\hline $2005-2009$ & 1.80 & 0.87 & 3.72 & 0.116 \\
\hline $2010-2013$ & 1.61 & 0.75 & 3.47 & 0.223 \\
\hline \multicolumn{5}{|l|}{$\begin{array}{l}\text { Walking to the diabetes } \\
\text { clinic }\end{array}$} \\
\hline Yes & 1.00 & & & \\
\hline No & 3.45 & 1.47 & 8.33 & 0.005 \\
\hline \multicolumn{5}{|l|}{$\begin{array}{c}\text { Frequency of coming for } \\
\text { review }\end{array}$} \\
\hline Very frequent & 1.24 & 0.55 & 2.83 & 0.604 \\
\hline Frequent & 0.73 & 0.41 & 1.32 & 0.299 \\
\hline $\begin{array}{r}\text { Irregular/ On doctor's } \\
\text { appointment/ When sick }\end{array}$ & 3.51 & 1.56 & 7.86 & 0.002 \\
\hline Somewhat/ Less frequent & & & & \\
\hline
\end{tabular}

\begin{tabular}{|c|c|c|c|c|}
\hline \multicolumn{4}{|c|}{$\begin{array}{l}\text { Time taken since arrival at the clinic up to the time } \\
\text { the client is through with the treatment }\end{array}$} & \\
\hline \multicolumn{5}{|l|}{$<30$ Minutes } \\
\hline $30-60$ Minutes & 1.64 & 0.74 & 3.63 & 0.223 \\
\hline $61-120$ Minutes & 0.80 & 0.32 & 1.99 & 0.636 \\
\hline $121-180$ Minutes & 2.96 & 1.32 & 6.61 & 0.008 \\
\hline$>180$ Minutes & 1.92 & 0.91 & 4.04 & 0.088 \\
\hline \multicolumn{5}{|c|}{$\begin{array}{c}\text { Duration of time taken determine } \\
\text { how serious the client take the } \\
\text { treatment }\end{array}$} \\
\hline Yes & 1.64 & 1.00 & 2.70 & 0.051 \\
\hline No & 1.00 & & & \\
\hline \multicolumn{5}{|c|}{$\begin{array}{l}\text { Clients food prepared most } \\
\text { of the time by children }\end{array}$} \\
\hline Yes & 2.00 & 1.06 & 3.78 & 0.031 \\
\hline No & 1.00 & & & \\
\hline \multicolumn{5}{|c|}{$\begin{array}{l}\text { Clients food prepared most } \\
\text { of the time by house help }\end{array}$} \\
\hline Yes & 1.70 & 0.83 & 3.47 & 0.147 \\
\hline No & 1.00 & & & \\
\hline \multicolumn{5}{|c|}{$\begin{array}{c}\text { Frequency of eating food that is not prepared according to } \\
\text { recommended diet }\end{array}$} \\
\hline Regularly & 4.17 & 1.29 & 13.53 & 0.017 \\
\hline Occasionally & 0.86 & 0.46 & 1.61 & 0.643 \\
\hline Not at all & 1.00 & & & \\
\hline \multicolumn{5}{|l|}{$\begin{array}{c}\text { Individualized diet has } \\
\text { benefited the client }\end{array}$} \\
\hline Yes & 1.00 & & & \\
\hline No & 2.50 & 0.75 & 8.33 & 0.136 \\
\hline
\end{tabular}

\section{Discussion}

Diabetes like any other chronic disease affects the quality of life and more so when complications associated with it set in not also forgetting the socioeconomic distress that it can cause to an individual and family. Individualized diet has been shown to prevent or reduce the onset of complications associated with diabetes and improve the quality of life.

Overall not following recommended diet in this study stood at $35.8 \%$ which is much lower than that from a study in Ethiopia (51.4\%) and $48 \%$ from a study carried out in the US [17]. This also concurs with information by most of the healthcare providers during this study who felt that majority the patients followed recommended diet. This percentage could be attributed to the fact that Kenyatta National Hospital being a hospital that is ISO certified has better standard in patient management.In this study, having a formal education was found to be associated with not following recommended medical nutrition therapy contrary to a study conducted at the Joslin Centre for diabetes, Pittsburg Pennsylvania that showed that increased education led to increased adherence to dietary recommendations [18]. This perhaps could be due to the fact that the educated are busy fending for their families leaving no time for them to take care of their specialized nutritional needs.

This study show statistically significant difference between travelling to the diabetes clinic by means other than walking in relation to uptake of recommended diet $(\mathrm{p}=0.002)$. In a study conducted in Nepal, it was found out that the adherence to dietary advice was higher among respondents who are nearer to hospital than those who are far with a statistically significant difference $(\mathrm{p}=0.013)$ [19]. This may be for similar assumptions that patients who are nearer have

\section{Volume 6 Issue 12, December 2017}




\section{International Journal of Science and Research (IJSR) \\ ISSN (Online): 2319-7064}

Index Copernicus Value (2016): 79.57 | Impact Factor (2015): 6.391

frequent visits to the hospital with better follow up than those who are far. Similar reason was shown in a study by Terri Travis patients. who visited the dietician more often and had more follow-ups were better able to adhere to diet [20]. Irregular visits to the diabetes clinic on doctor's appointment or when sick and taking long time waiting to be treated at the hospital, were found to be contributing factors. A study conducted in Bahrain showed that lack of proper professional dietary assessment follow-up and advice by health care providers were influencing factors on dietary practice of type 2 diabetic patients [21]. Irregular appointments means there is no regular follow up on the patient which impacts negatively as the patient does not get regular medical checkup as well as nutritional assessment and advice. Taking so long at the clinic is always perceived as time wasting by patients hence the reason why some patients may not be taking the advice given seriously. The issue could be as a result of the hospital not having adequate healthcare providers as stated by majority of the healthcare providers during in-depth interviews. In a study conducted in India showed that those who visited a dietician where more likely to follow recommended diet than those who had merely been advised by the physicians [22].

The patients who were regularly consuming food that was not prepared according to their nutritional advice according to this study had a high chance of not following recommended diet. A study conducted in Botswana showed similar findings [23]. This could be as a result difficult in revealing that one is diabetic especially when going for meals at work place or during social gatherings.

\section{Conclusion}

The uptake of recommended nutritional diet among type 2 diabetes patients is fairly high with $35.8 \%$ not following recommended diet. To get this population also to follow recommended diet, the contributory factors that have been highlighted in this study as being the reason for not following should be looked into. This will go a long way in enhancing uptake of recommended diet among type 2 diabetic who are unable to follow recommended diet.

The hospital needs to employ more healthcare providers more so nutritionists to be able to serve the high number of patients at the clinic. Currently the clinic has only one nutritionist.

\section{References}

[1] Delamater A M. Improving Patients Adherence. Diabetes Care.2007 30:1107-1112.

[2] Narayan KMV, Zhang P, KanayaAM , et al. Diabetes: The Pandemic and Potential solutions. In: Jamison DT,Breman JG, Measham AR, et al., Disease control Priorities in Developing Countries. $2^{\text {nd }}$ Edition. Washington (DC): World Bank; 2006 Chapter 30.p. 591-603.

[3] Veterans with diabetes and poor glycemic control. J Gen Inter Med. 2007; 22(4):442-7. IDF Diabetes Atlas $6^{\text {th }}$ Edition.
[4] International Diabetes Federation. IDF Diabetes Atlas, $6^{\text {th }}$ Edition. Brusels, Belgium: International diabetes Federation; 2013.

[5] Guariguata L, Whiting D, Hambleton I, Beagley J, Linnenkamp U, Shaw J: Global estimates of diabetes prevalence for 2013 and projections for 2035 for the IDF Diabetes Atlas. Diabetes Research and Clinical Practice 2013 [PubMed]

[6] World Health Organization, Global Report on Diabetes.Geneva, 2016.Accessed 30 August 2016.

[7] International Diabetes Federation, Diabetes Atlas, Fifth Edition (accessed November 16, 2011).

[8] Lanting LC, Joung IM, Vogel I, et al. Ethinic differences in outcomes of diabetes care and the role of self-management behavior. Patient Educ Couns.2008; 72(1):20-8.

[9] Nelson KM, McFarland L, Reiber G. Factors Influencing disease self-management among

[10] King H, Aubert RE, Herman WH. Global burden of diabetes, 1995-2025: prevalence, numerical estimates, and projections. Diabetes Care. 1998 Sep; 21(9):141431. PMID:9727886.

[11] Motilch ME. Meeting and maintaining treatment goals for patients with diabetic nephropathy. Diabetes Dialogue Winter2005/2006.International Medical Press.USA.

[12] Shamsi N, Shehab Z, AlNahash z, et al. Factors Influencing Dietary Practice Among Type 2 Diabetic Patients in Bahrain; 2011.

[13] Morisky D E. Adherence or compliance behavior. Encyclopedia of Public Health, May 2009.

[14] Kravitz R L, Hays R D, Sherbourne C D et al; Recall of recommendations and adherence to advice among patients with chronic medical conditions. Arch Intern Med 153: 1869-1878, 1993.

[15] Youngman J. Type 2 diabetes dietetic: best practice guidelines for management of type 2 diabetes. Queensland: Queensland Health and Brisbane Inner South Division of General Practice; 2000.

[16] Ekore RI, Ajayi IO, Ekore JO (2008) Dietary management of diabetes: a practical approach for primary care physicians in Nigeria. Diabetes 16:13-14.

[17] Anderson JW, Gustafson NJ. Adherence to highcarbohydrate, high-fiber diets.Diabetes Educ 1998; 15:429-434.Doi: $\quad 10.11177 / 0145721798901500512$ [PubMed] [Cross Ref].

[18] Paes AHP, Bakker A, Soe-Agnie CJ: Impact of dosage frequency on patient compliance, 1997. Diabetes care 20:1512-1517.

[19] Janaki P et al; Factors associated with nonadherence to diet and physical activity among Nepalese type 2 diabetes patients; a cross sectional study 2014.

[20] Travis T. Patient perception of factors that affect adherence to dietary regimens for diabetes mellitus.Diabetes Educ. 1997; 23:152-156.doi 10.1177/014572179702300205. [Pubmed] [Cross Ref].

[21] Shamsi N, Shehab Z, AlNahash Z, AlMuhanadi S, AlNasir F: Factors Influencing Dietary Practice among Type 2 Diabetics. Bahrain Medical Bulletin 2013, 35(3).

[22] Kapur K, Kapur A, Ramachandran S, Mohan V, et al. Assoc Physicians India. Barriers to changing dietary behavior. 2008. [PubMed]. 


\section{International Journal of Science and Research (IJSR) \\ ISSN (Online): 2319-7064}

Index Copernicus Value (2016): 79.57 | Impact Factor (2015): 6.391

[23] Bisiriyu G. Non -Adherence to Lifestyle Modification Recommendations (Diet and Exercise) Among Type 2 Diabetes Mellitus Patients Attending Extension Ii Clinic in Gabrone Botswana. 2008. M Med thesis.

Volume 6 Issue 12, December 2017

www.ijsr.net

Licensed Under Creative Commons Attribution CC BY 